\title{
CHRONIC INTERSTITIAL PNEUMONITIS IN DOGS NATURALLY INFECTED WITH Leishmania (Leishmania) chagasi: A HISTOPATHOLOGICAL AND MORPHOMETRIC STUDY
}

\author{
Ricardo GONÇALVES(1), Washington Luiz TAFURI(4), Maria Norma de MELO(3), Pedro RASO(4) \& Wagner Luiz TAFURI(2)
}

\begin{abstract}
SUMMARY
Eighteen mongrel dogs of unknown age and naturally infected with Leishmania (Leishmania) chagasi, were obtained from the City Hall of Belo Horizonte, Brazil. Four dogs were used as control. Lung samples were obtained and immediately fixed in formalin. The histopathological picture of all lung tissue sections was a chronic and diffuse interstitial pneumonitis. The thickened interalveolar septa were characterized by the cellular exudate (mostly macrophages, lymphocytes and plasmocytes) associated with collagen deposition. Morphometric analysis showed greater septal thickness in the infected animals than in controls. In fact, the morphometric study of collagen stained with ammoniac silver confirmed a larger deposition of collagen in the infected animals. The parasitologic method was carried out during the study of the lesions on the slides. However, we did not observe any correlation between the histopathologic and morphometric data and the clinical status of the animals. We conclude that the pulmonary lesions observed in all naturally infected dogs were correlated with the disease and that the morphometric method used was satisfactory for the analysis of septal thickness and of increased collagen deposition, confirming the presence of fibrosis.
\end{abstract}

KEYWORDS: Chronic Interstitial Pneumonitis; Dogs; Histopathology; Morphometric analysis; Leishmania (Leishmania) chagasi.

\section{INTRODUCTION}

Interstitial pneumonitis in visceral leishmaniasis was initially described in humans in $1959^{3}$ and later confirmed by other authors ${ }^{4,6,12,19}$. In dogs, pulmonary lesions are very similar to those observed in humans, and were previously characterized by some authors as interstitial pneumonitis mainly characterized by thickening of alveolar walls associated with the presence of a chronic cellular exudate mainly consisting of macrophages ${ }^{1,23}$. Later on, similar lesions were described in dogs experimentally infected with Leishmania (Leishmania) chagasi $^{13}$.

In Brazil, DUARTE et al. (1986) described the histological pulmonary alterations of dogs naturally infected with Leishmania (Leishmania) chagasi. In a study performed with 41 naturally infected dogs they detected interstitial pneumonitis in $81.5 \%$ of the animals and no other kind of pulmonary alteration, such as bronchopneumonia. An immunoenzymatic study with specific antibodies (PAP) showed particulate antigenic material and/or amastigotes of Leishmania in the inter-alveolar septa where interstitial pneumonitis was present ${ }^{11}$.

As far as we know, a specific pulmonary symptom occurring during visceral leishmaniasis has not been described. On the other hand, there are many reports of dry coughing as a symptom of visceral leishmaniasis in human beings, but there are no references about the correlation between this symptom and interstitial pneumonitis ${ }^{7,12,14,16,19}$. Some authors have proposed compression of the spleen against the vagus nerve $\mathrm{e}^{16}$ as the cause of this symptom and terminal broncopneumonitis as a terminal stage of the disease, or at least the presence of leishmanias in the alveolar septa ${ }^{2}$.

The pathogenesis of the pulmonary alterations occurring in visceral leishmaniasis has not been completely elucidated, especially in persistent lesions where the parasite was not found. Moreover, interstitital pneumonitis is an asymptomatic lesion and few studies have investigated the pathogenesis of this disease in dogs. Thus, the aim of the present study was to characterize the interstitial pneumonitis occurring in canine visceral leishmaniasis on the basis of histopathological and morphometric aspects of the lesions associated with the different clinical forms of the disease in the dog.

\section{MATERIAL AND METHODS}

Animals: Eighteen mongrel dogs of unknown age (nine females and nine males) were obtained from the City of Belo Horizonte (Zoonosis Department), MG, Brazil. All dogs were positive for Leishmania by direct immunofluorescence (RIFI) and complement fixation tests (RFC).

This group of naturally infected animals was divided into three groups of six animals each. Tissue touch preparations of liver, spleen and bone

Financial Support: FAPEMIG (CDS 2263/97) and CAPES, UFMG.

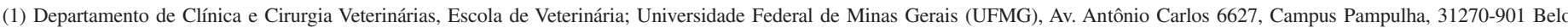
Horizonte, MG, Brazil. Phone/fax: 5531 3499-2889.

(2) Departamento de Patologia Geral, Instituto de Ciências Biológicas (ICB), Universidade Federal de Minas Gerais (UFMG), Brazil.

(3) Departamento de Parasitologia, Instituto de Ciências Biológicas (ICB), Universidade Federal de Minas Gerais (UFMG), Brazil.

(4) Departamento de Anatomia Patológica e Medicina Legal, Faculdade de Medicina, Universidade Federal de Minas Gerais

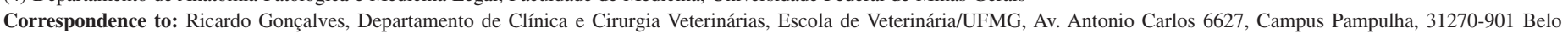
Horizonte, MG, Brasil. e-mail: pepe@icb.ufmg.br 


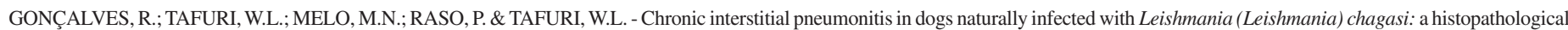
and morphometric study. Rev. Inst. Med. trop. S. Paulo, 45(3):153-158, 2003.

marrow were also positive for all animals. The control group consisted of four dogs seronegative for Leishmania.

Dogs were clinically classified according to previous studies ${ }^{15}$ and to our own experience as follows:

Group I: Symptomatic - animals that exhibited the classical signs of the disease such as cutaneous alterations (alopecia, dry exfoliative dermatitis or ulcers), onychogryphosis, keratoconjunctivitis, cachexia, and anemia.

Group II - Oligosymptomatic - animals exhibiting some clinical signs of the disease and/or lesions such as lymphoid adenopathies, moderate weight loss and/or dull brittle hair accompanied by cutaneous lesions.

Group III - Asymptomatic - apparently healthy animals without signs or typical clinical symptoms of visceral leishmaniasis.

Histopathology: Dogs were sacrificed with a lethal dose of $33 \%$ Thiopental. Lungs, spleen, liver and lymph nodes were macroscopically evaluated. Four to five lung fragments were randomly collected from the pulmonary lobules.
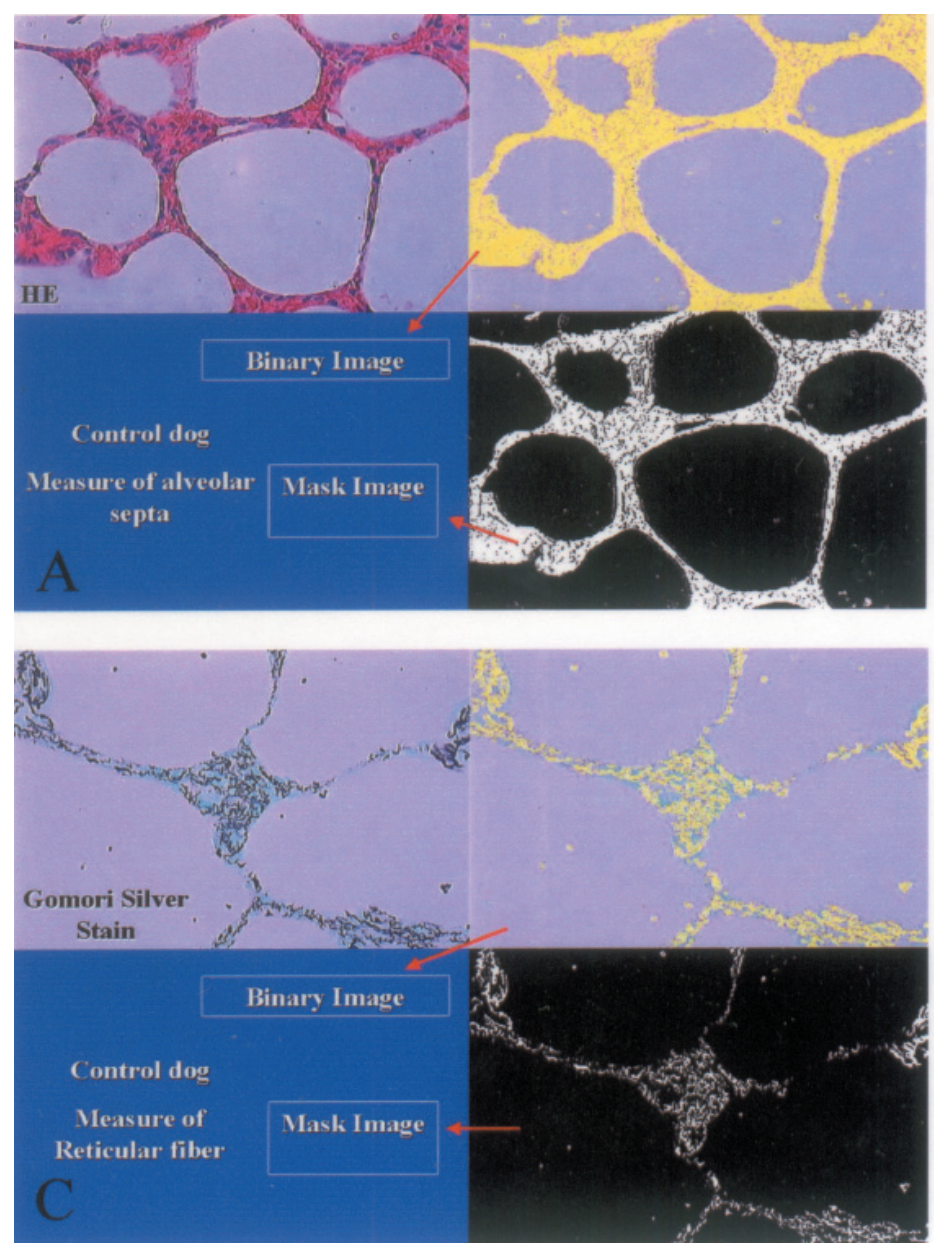

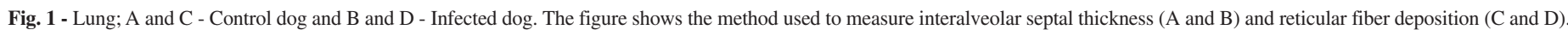
Note the significant difference between the values for a control animal (A) and an infected animal (B). 
Statistical analysis: The results obtained in a fully randomized design were log transformed and the means for each group were compared by the Student $\mathrm{t}$ test $^{21}$. A $P$ value of less than 0.05 was considered significant.

\section{RESULTS}

A chronic interstitial pneumonitis with a remarkable thickening of the inter-alveolar septa was the principal lesion observed in all infected animals of all clinical groups. In 7 out of the 18 dogs the inflammatory reaction was not evenly diffuse but rather consisted of systematized foci. When inflammation was intense it tended to become evenly distributed. This pattern was observed in 11 out of the 18 dogs (Fig. 2, 3).

In general, the cellular exudate was predominantly characterized by mononuclear cells, mostly lymphocytes, macrophages and plasmocytes,

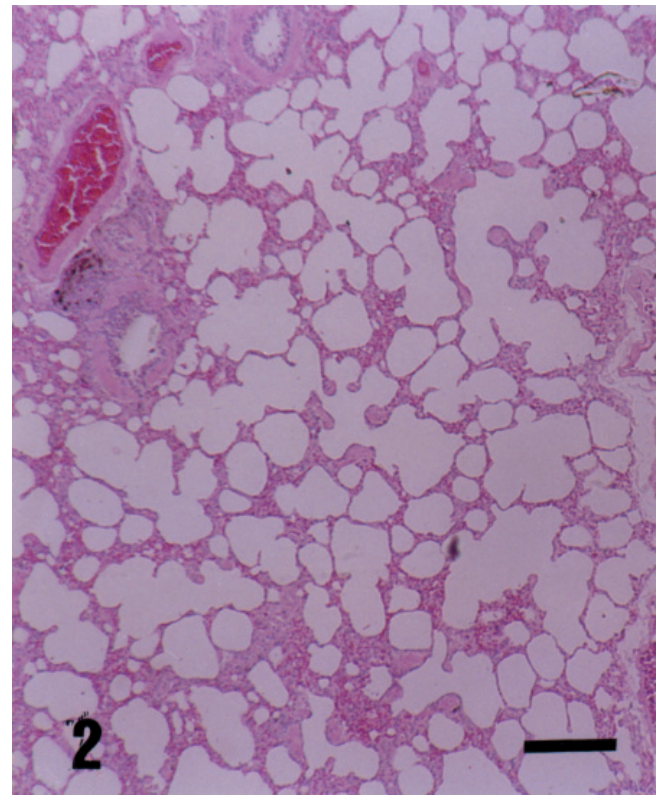

Fig. 2 - Lung; Control dog. Note the normal alveolar septa. HE. Bar $=174 \mu \mathrm{m}$.

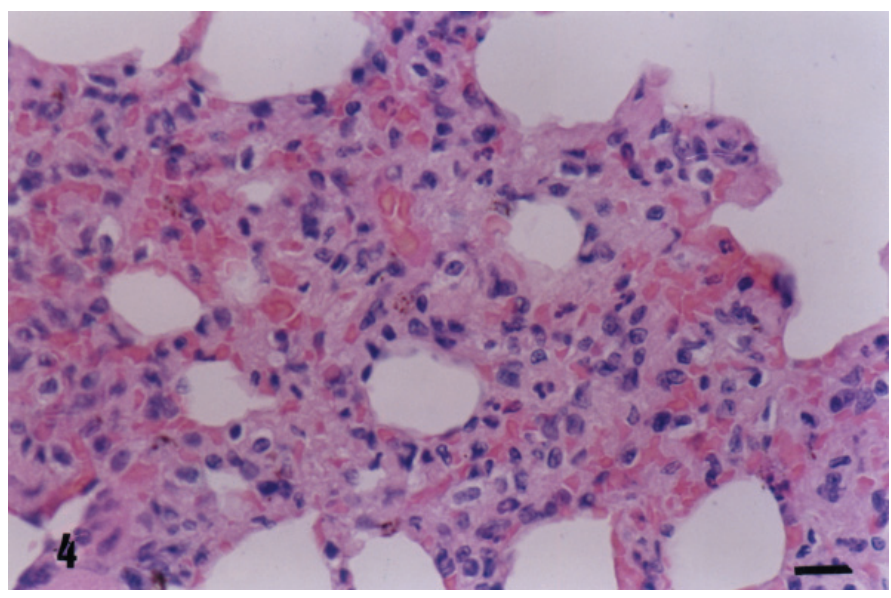

Fig. 4 - Lung from a naturally infected dog. Intense septal thickening associated with intense and diffuse chronic interstitial pneumonitis is observed. HE. Bar $=25 \mu \mathrm{m}$. with rare eosinophils and neutrophils. Macrophages were very numerous in septa, rare in alveolar spaces and had large shapeless nuclei with irregular borders. However we did not observe Leishmania amastigotes in these cells in any animal (Fig. 4).

Morphometry for evaluation of alveolar septa thickening was performed using histologic sections of lung stained with HE. This analysis confirmed quantitatively the difference between infected dogs and controls, as demonstrated in Figure 5. However, no significant differences were observed among naturally infected dogs.

Inflammatory lesions of the alveolar septa tended to show fibrosis in all cases. In fact, Gomori's ammoniac silver staining revealed numerous reticular fibers within the alveolar septa. The reticular fibers were deeply stained and formed very dense tangled structures (Fig. 6). More pronounced deposition of reticular fibers was present where inflammatory foci were more intense, and thickening was more accentuated when compared with the lung of control animals (Fig. 7). In the terminal and

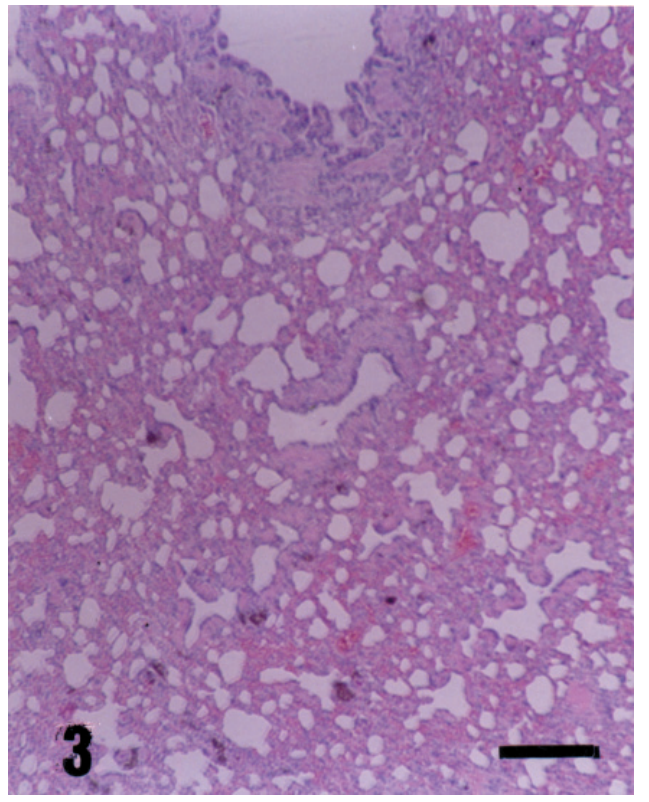

Fig. 3 - Lung from a naturally infected dog. Note the thickened inter-alveolar septa in the naturally infected dog with an intense and diffuse chronic interstitial pneumonitis. HE. Bar $=174 \mu \mathrm{m}$.

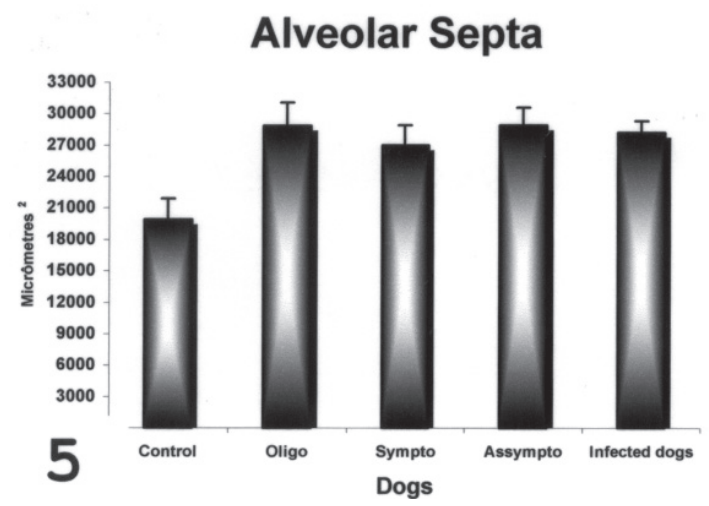

Fig. 5 - Morphometric analysis of thickening of the inter-alveolar septa in control and infected animals (Oligosymptomatic, Symptomatic and Asymptomatic). Statistical analysis showed significant differences between all groups and control animals. 


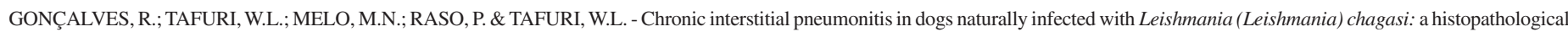
and morphometric study. Rev. Inst. Med. trop. S. Paulo, 45(3):153-158, 2003.

respiratory bronchioles the smooth musculature was interrupted by large quantities of these fibers. In fact, they formed structures similar to "balls of black wool", and many of them projected into the lumen of the alveolus or bronchiole (Fig. 8).

Morphometric analysis of the silver-stained reticular fibers in the alveolar septa confirmed the early qualitative microscopic evaluation and revealed more numerous reticular fibers in the infected animals compared to the control group ( $\mathrm{p}>0.05$ ). Differences between values were found independently for the various clinical forms of the disease (Fig. 9).

Besides the inter-alveolar septal lesions, a remarkable hyperplasia of the epithelium of terminal and respiratory bronchioles was observed. Sometimes the epithelium consisted of 4 to 5 layers of cuboid non-ciliated cells (Fig. 10).

Sections stained with Grocot and Good Pasture were negative for fungi and bacteria, respectively, in all groups, including animals from the control group.

\section{DISCUSSION}

Pneumonitis can be histologically classified as cellular, fibroticcellular or fibrotic ${ }^{11}$. The animals used in this study exhibited a fibroticcellular histopathological picture.

The influence of the inflammatory infiltrate on the interstitial pneumonitis of visceral leishmaniasis seems to be very important in the pathogenesis of the lesions. Pulmonary defense mechanisms are somewhat different than those of other tissues ${ }^{18}$. The lungs react to constant aggressions and many times seem not to develop inflammation. Pulmonary macrophages exhibit a microbicidal action even when not activated; and when activation takes place they are able to eliminate enormous quantities of bacteria that enter the lungs through the airways ${ }^{5}$.

In canine visceral leishmaniasis it is very common to find high tissue parasite burdens in liver, spleen, lymph nodes, bone marrow and skin. In fact, in this study we observed many amastigote forms of Leishmania in all organs examined (spleen, liver and lymph nodes) of all infected dogs. However, parasites are hard to demonstrate in the lungs, even in human disease $\mathrm{s}^{3,4,19}$. Our histological results showed the absence of parasites in the lungs. These results are in accordance with other studies which describe low pulmonary parasitism in the lungs of the $\operatorname{dog}^{10,11,13,23}$.

Mechanisms to explain the pathogenesis of the inflammatory lesions in the visceral leishmaniasis have been considered. Some authors have suggested the involvement of immune complex deposits in the vascular endothelium or interstitium generating chemotaxis and establishing a local inflammatory response mainly provoking vasculitis in many $\operatorname{organs}^{8,17,22}$.

In the present study we showed that the inflammatory response mainly consisted of a mononuclear cellular exudate and a fibrotic reaction. We believe that the intense fibrosis observed could be due to the continued stimulus provoked by parasites or antigens that come to the lungs. Their presence activates macrophages which then activate the inflammatory reaction. In addition, besides the absence of parasites in the lungs, we believe that destruction of the parasites could be occurring in this organ, with only residual particulate material remaining. This is a possibility since these cells have a different physiology in the lungs. For example, the power of pulmonary macrophages to eliminate pathogens might be connected to a greater superoxide production inside the alveolus, acting like the granulocyte mieloperoxidase-hydrogen peroxide halide pathway ${ }^{18}$. In fact, granulocytes (polymorphonuclear neutrophils) play an important role in Leishmania infection ${ }^{20}$.

Previous studies demonstrated that in lungs the macrophages work better when they are in the basal state. "The degree of the inflammatory response appears to be carefully regulated to maintain physiologic functions while providing rapid eradication of inhaled microorganisms". It seems that macrophages might be in a kind of "basal activation". This "macrophage status" induces a fast response to the pathogens, but without provoking an inflammatory response strictly speaking 9 . This fact may prevent lesions to the lungs, since these cells can provoke tissue damage. Pulmonary macrophages are able to produce free radicals, proteases, chemokines, and growth factors 5 . The production of growth factors could explain the epithelial hyperlasia of the bronchioles observed and shown in Fig. 6.

Based on the present results, we can conclude that chronic interstitial pneumonitis coexists with lesions of other organs, and that there are no qualitative or quantitative differences between the various clinical forms of canine visceral leishmaniasis. Cellular exudation and fibrosis are the mechanisms responsible for the remarkable focal and/or diffuse thickening of inter-alveolar septa.

Also, it is important to mention that the lung has peculiar anatomical and functional characteristics and should be considered individually in systemic diseases, such as visceral leishmaniasis. Participation of macrophages also seems essential, since the constant inflammatory stimulus leads to a hyperactivity of these cells, which can ultimately cause tissue lesions.

In the present study we demonstrated a morphometric method for the analysis and quantitation of the real thickening of inter-alveolar septa during interstitial pneumonitis.

\section{RESUMO}

\section{Pneumonia intersticial crônica em cães naturalmente infectados com Leishmania (Leishmania) chagasi: estudo histopatológico e morfométrico}

Neste estudo, foram utilizados dezoito cães naturalmente infectados com Leishmania (Leishmania) chagasi, sem raça e idade definidos, cedidos pelo Centro de Contole de Zoonoses da Cidade de Belo Horizonte. Quatro cães foram utilizados como controle. Durante a necropsia, amostras do pulmão foram coletadas, e imediatamente fixadas em formalina. A histopatologia mostrou principalmente uma pneumonite intersticial crônica, produtiva, difusa e intensa. Os septos inter-alveolares espessados, eram constituídos principalmente por um infiltrado de células inflamatórias, em sua maioria, macrófagos, linfócitos e plasmócitos, além de fibroblastos e fibras colágenas. A análise morfométrica do espessamento septal mostrou diferença significativa entre animais infectados e controle. De fato, a análise morfométrica do colágeno, corado 


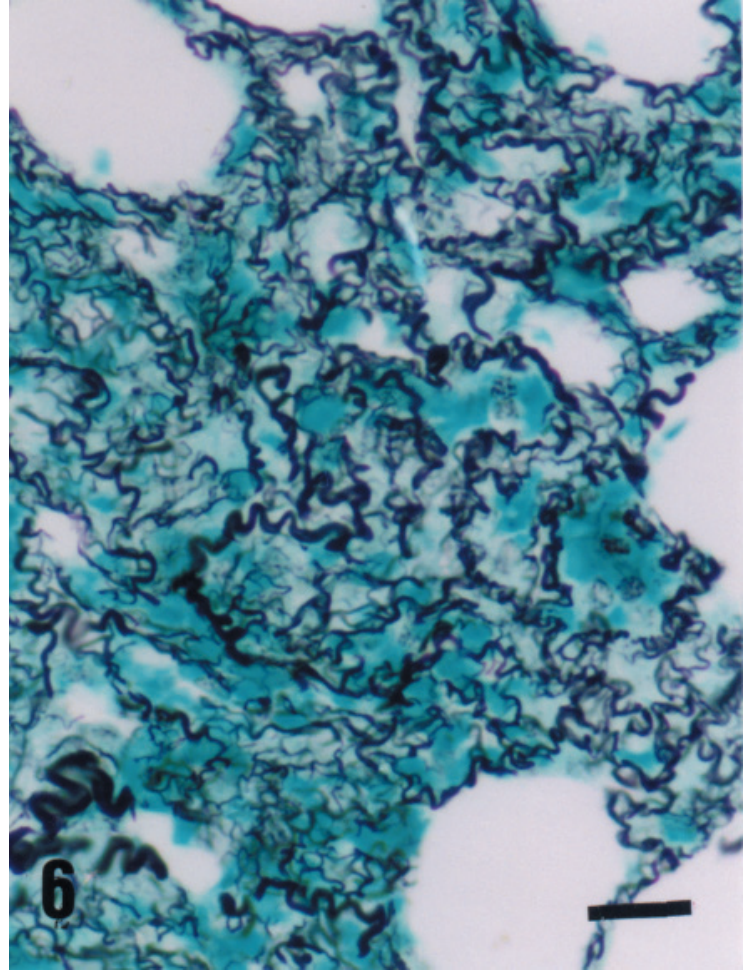

Fig. 6 - Lung from a naturally infected dog. Note the intense fibropoiesis in the smooth muscle of bronchioles, which still exhibit intense hyperplasia of the epithelium. Gomori's Ammoniac Silver. Bar $=50 \mu \mathrm{m}$.

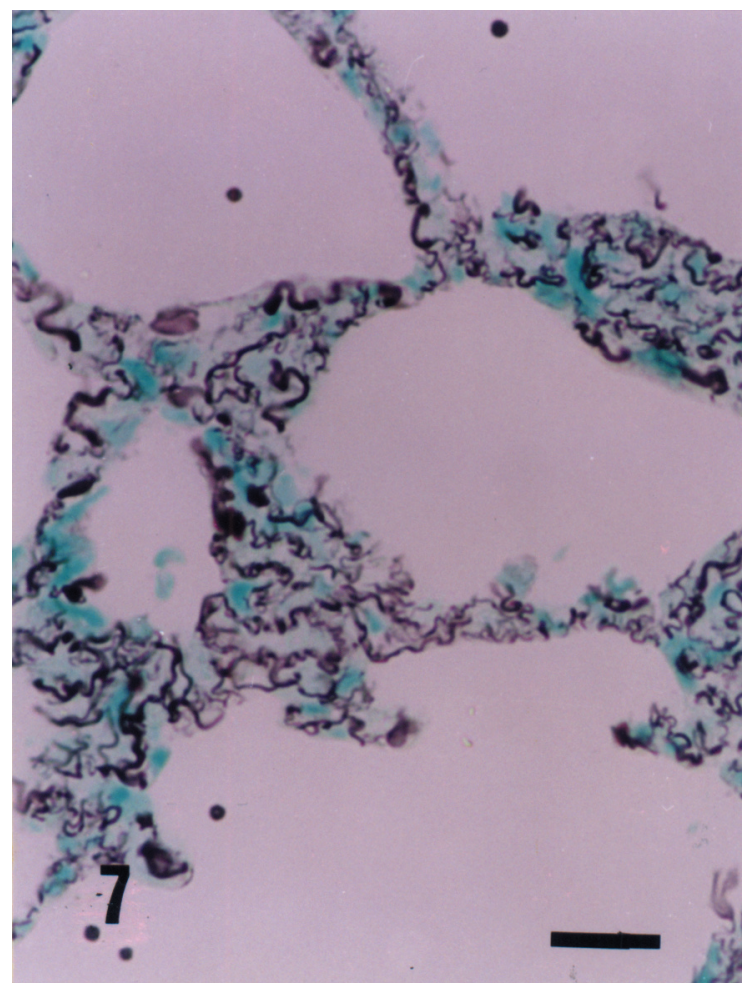

Fig. 7 - Lung from a control dog. Reticular collagen fibers stained black showing normal deposition in the alveolar septa. Gomori's Ammoniac Silver. Bar $=12.5 \mu \mathrm{m}$.

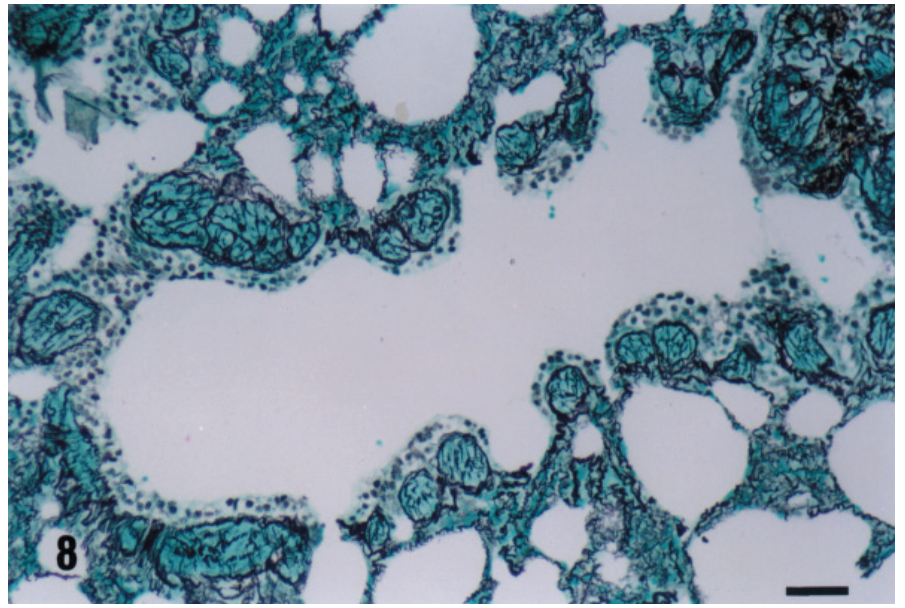

Fig. 8 - Lung from a naturally infected dog. Reticular fibers are stained black. Observe the intense fibrillopoiesis showing dense and coiled fibers ("wool nodules"). Gomori's Ammoniac Silver. Bar $=12.5 \mu \mathrm{m}$

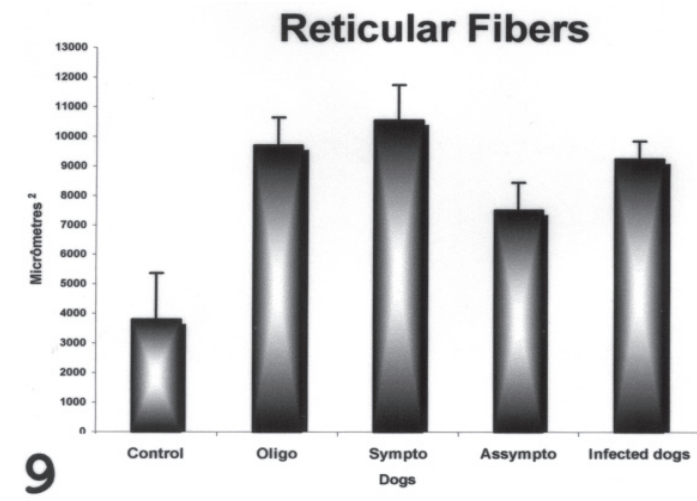

Fig. 9 - Morphometric analysis of reticular fibers stained with Gomori's Ammoniac Silver Statistical analysis showed significant differences between all groups and control animals.

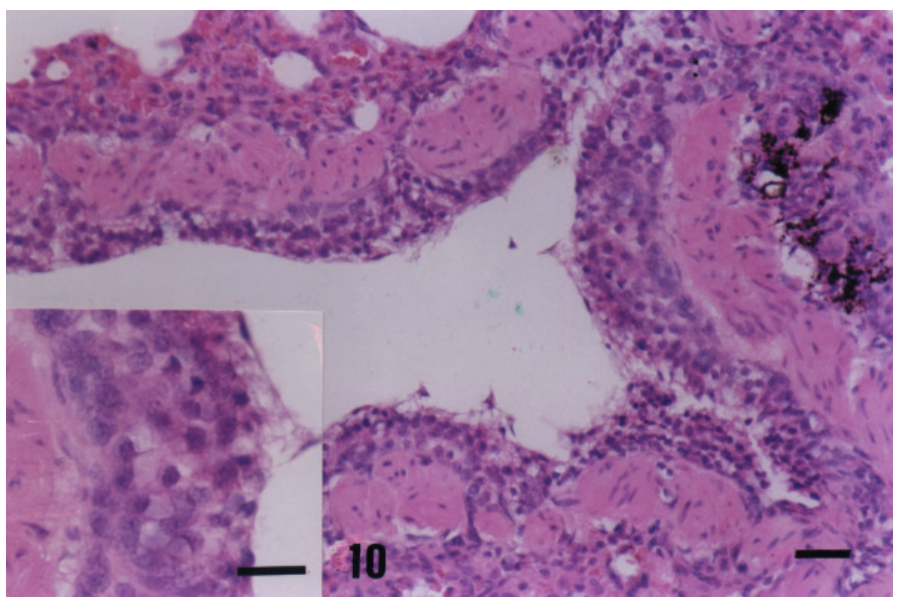

Fig. 10 - Lung from a naturally infected dog. Hyperplasia of the epithelium. Presence of many cells projecting into the lumem. HE. Bar $=25 \mu \mathrm{m}$. 


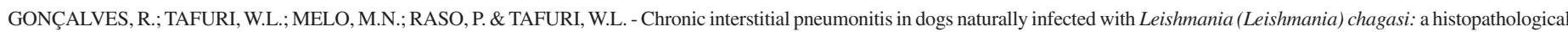
and morphometric study. Rev. Inst. Med. trop. S. Paulo, 45(3):153-158, 2003.

pela prata, confirmou um aumento na deposição de colágeno em todos os animais infectados. $\mathrm{O}$ exame parasitológico foi ralizado durante a análise histopatológica, em todos os casos estudados. Contudo neste trabalho, não observamos qualquer correlação entre os achados histopatológicos e morfométricos quando relacionados aos cães em diferentes formas clínicas. Concluímos que as lesões, encontradas nos cães naturalmente infectados, tem correlação com a doença, e que o método de análise morfométrica utilizado apresentou resultados satisfatórios quanto à análise do espessamento septal e ao aumento da deposição de colágeno, confirmando a fibrose.

\section{REFERENCES}

1. ANDERSON, D.C.; BUCKER, R.G.; GLENN, B.L. \& MACVEAN, D.W. - Endemic canine leishmaniasis. Vet. Path., 17: 94-96, 1980.

2. ANDRADE, Z.A. - Anatomia patológica da leishmaniose visceral (calazar). Arq. bras Med. naval, 7: 7346-7472, 1958

3. ANDRADE, Z.A. - Pneumonite intersticial no calazar. Hospital (Rio de J.), 55: 371$381,1959$.

4. ANDRADE, Z.A. \& ANDRADE, S.G. - Alguns novos aspectos da patologia do calazar (estudo morfológico de 13 casos necropsiados). Rev. Inst. Med trop. S. Paulo, 8: 259-266, 1966.

5. BITTERMAN, P.B.; SALTZMAN, L.E.; ADELBERG, S.; FERRANS, V.J. \& CRYSTAL, R.G. - Alveolar macrophage replication. J. clin. Invest., 74: 460-469, 1984.

6. BOGLIOLO, L. - Sulla Anatomia pathologica della leishmaniose visceral dell'uomo. Arch. ital. Sci. med. colon., 15: 588, 1934.

7. CHAGAS, E. \& CHAGAS, A.W. - Notas sobre a epidemiologia da leishmaniose visceral americana. Hospital (Rio de J.), 13: 147-180, 1938.

8. CIARAMELLA, P.; OLIVA, G., LUNA, R.D. et al. - A retrospective clinical study of canine leishmaniasis in 150 dogs naturally infected by Leishmania infantum. Vet. Rec., 22: 539-543, 1997.

9. COONROD, J.D. - Role of leukocytes in lung defenses. Respiration, 55(suppl. 1): 9-13, 1989.

10. DUARTE, M.I.S. \& CORBETT, C.E.P. - Histopathological and ultrastructural aspects of interstitial pneumonitis of experimental visceral leishmaniasis. Trans. roy. Soc. trop. Med. Hyg., 78: 683-688, 1984.
11. DUARTE, M.I.S.; LAURENTI, M.D.; NUNES, V.L.B. et al. - Interstitial pneumonitis in canine visceral leishmaniasis. Rev. Inst. Med. trop. S. Paulo, 28: 431-436, 1986.

12. DUARTE, M.I.S.; MATTA, V.L.R.; CORBETT, C.E.P. et al. - Interstitial pneumonitis in human visceral leishmaniasis. Trans. roy. Soc. trop. Med. Hyg., 83: 73-76, 1989.

13. KEENAN, C.M.; HENDRICKS, L.D.; LIGHTNER, L. \& JOHNSON, A.J. - Visceral leishmaniasis in the German shepherd dog. II. Pathology. Vet. Path., 21: 80-86, 1984.

14. LIPSCOMB, F.E. \& BIGSON, M.O.J. - Visceral leishmaniosis (Kala-azar) in an adult contracted in Malta. Brit. med. J., 1: 492-493, $1944 .$.

15. MANCIANTI, F.; GRAMICCIA, M.; GRANDONI, L. \& PIERI, S. - Studies on canine leishmaniasis control. 1. Evolution of infection of different clinical forms of canine leishmaniasis following antimonial treatment. Trans. roy. Soc. trop Med. Hyg., 82: 566-567, 1988.

16. NAPIER, L.E. - The principles and practice of tropical medicine. New York, The MacMillan, 1946. p. 917.

17. PUMAROLA, M.; BREVIK, L.; BADIOLA, J. et al. - Canine leishmaniasis associated with systemic vasculitis in two dogs. J. comp. Path., 105: 279-286, 1991.

18. QUIE, P.G. - Lung defense against infection. J. Pediat., 108: 813-816, 1986.

19. RASO, P. \& SIQUEIRA, J.T.D. - Subsídio ao conhecimento da anatomia patológica da leishmaniose visceral, com especial referência às lesões pulmonares e cardíacas. Hospital (Rio de J.), 65(6): 145-163, 1964.

20. ROUSSEAU, D.; DEMARTINO, S.; FERRUA, B. et al. - In vivo involvement of polymorphonuclear neutrophils in Leishmania infantum infection. BMC Microbiol., 1: 17, 2001.

21. SAMPAIO, I.B.M. - Estatística aplicada à experimentação animal. Belo Horizonte, Fundação de Ensino e Pesquisa em Medicina Veterinária, 1998. p. 221.

22. TAFURI, W.L.; MICHALICK, M.S.M.; DIAS, M. et al. - Estudo ao microscópio óptico e eletrônico, do rim de cães natural e experimentalmente infectados com Leishmania (Leishmania) chagasi. Rev. Inst. Med. trop. S. Paulo, 31: 139-145, 1989.

23. TRYPHONAS, L.; ZAWIDZKA, Z.; BERNARD, M.A. \& JANZEN, E.A. - Visceral leishmaniasis in a dog: clinical, hematological and pathological observations. Canad. J. comp. Med., 41: 1-12, 1977.

Received: 9 January 2003

Accepted: 22 April 2003 